\title{
LA COMPASIÓN DIFÍCIL
}

\author{
DIFFICULT COMPASSION
}

\author{
Ana Orellana García \\ Paula Román Cañamero \\ Regina Lagos González
}

DOI: 10.26754/ojs_arif/a.rif.202014165

Chantal Maillard: La compasión difícil. Barcelona: Galaxia Gutenberg, 2019. 218 pp.

Una obra escrita desde las entrañas: esta sería una de las primeras descripciones que se pueden dar de la obra de Chantal Maillard (1951). La compasión difícil es un texto desgarrador cargado de contenido filosófico que párrafo tras párrafo desvela algunas partes de la condición humana, poniendo el foco en la crudeza de la existencia que sistemáticamente se ha tratado de obviar, y casi siempre conseguido. Resulta difícil no situarla cerca de los grandes pensadores pesimistas a quienes con aprensión se trata de mantener fuera del canon: Leopardi, Schopenhauer (y, más cerca de nosotros, la Crítica de la moral afirmativa de Julio Cabrera). Su escritura profundamente personal se combina con un formato que resquebraja todas las categorías literarias, haciendo de esta una obra sugerente y cautivadora estructurada alrededor de una actitud, la compasión, que, como mínimo, ha de tenerse en cuenta en este mundo complejo y plural. "Una ética de la compasión no convertirá la vida en algo mejor. El sistema del hambre seguirá siendo el que es. Pero tal vez sea más soportable” (p. 124).

El Hambre, la rebeldía, el sufrimiento, los dioses, la libertad, el suicidio y, como es evidente, la compasión, son algunos de los temas que la filósofa nacida en Bruselas revisa y dota de su propio significado. Esta arriesgada apuesta, tanto en las formas como en el contenido, ha debido de cautivar a Galaxia Gutenberg, editorial con la que publica su tercer libro (precedido por La mujer de pie (2015) y La razón estética (2017)) y que califica el texto de "perturbador", dejando claro que para su lectura son necesarios tanto la inteligencia como el valor. 
Reconocida poeta, traductora de Henri Michaux y especialista en María Zambrano y en las filosofías de la India, hace tiempo que Maillard se identifica más con la literatura que con la filosofía más académica. Prueba de ello es la estructura de la obra, desplegada en tres partes que combinan capítulos cortos cargados de aforismos con un final a modo de diálogo, que bien podría entenderse desde el formato socrático desarrollado por Platón, como una representación teatral, o como propuesta cinematográfica en una revisión personal del mito de Medea. Tres partes en las que no para de resonar una pregunta: "¿Cómo comprender a Medea" (p. 125), y compadecerla? ¿Cómo compadecer a todos los otros? Porque lo difícil nunca fue compadecer a las víctimas, ni a quien tenemos cerca, sino sentir compasión por ese "otro" que nos es ajeno, por ese "otro" al que llamamos culpable.

En la primera parte de la obra, la más extensa y plagada de matices, Maillard despliega de manera panorámica el concepto de Hambre mientras introduce una gran variedad de ideas que transitan desde los orígenes del universo marcado por los dioses, pasando por un análisis profundo de las creencias que se presentan como sustentadoras de toda forma de ignorancia, hasta las claves para el desarrollo de una ética de la compasión. Este último concepto, central para el conjunto de la obra, retoma la mayoría de edad kantiana que implica el conocimiento de sí y la capacidad de salirse de los propios límites. La ética de la compasión, además, conlleva el ser capaces de ver cómo se va tejiendo nuestra historia, pero dando un paso más y logrando la no identificación con ella. Es en esa neutralidad donde se abre un espacio que permite que aparezca la libertad radical que, siguiendo la línea de Schopenhauer, otorga la posibilidad de negar la propia voluntad de vivir.

Estas reflexiones, impregnadas de un tinte realista radical y que en muchos casos navegan en el pesimismo, revelan la violencia de la propia existencia, el sufrimiento que ya hizo notar Siddharta Gautama y del que la experta en Filosofía de las Religiones se nutre. Los tabús quedan dinamitados: el suicidio es entendido como una posibilidad más, como una elección lícita que bajo ciertas condiciones también es un acto de libertad (y quizá el supremo acto de libertad). Pero el giro de $180^{\circ}$ continúa. Amor o belleza también son vistos desde otra óptica, la de "el triple engaño", donde se pone en cuestión que "la vida es buena, la vida es bella, la vida es real" (p. 67). Sus planteamientos, tal y como se puede ver, incómodos, críticos y alejados de convencionalismos, descansan sobre una propuesta que pone en duda toda creencia y construye desde otra base, desde el respeto que desplaza los límites del marco de pertenencia a todo lo que sufre, a todo lo que vive.

Ya en los comienzos de la segunda parte del libro Chantal Maillard se adentra en profundidad en el análisis de la compasión. Para ello, la autora se sirve de la 
versión de Lars von Trier sobre el mito de Medea, haciendo hincapié en el papel de Mérmeros, personaje que, desde su inocencia, encarna a la perfección la pura compasión. El hijo de Medea refleja esta actitud como la comprensión profunda del otro, del que solo nos distancian las ilusiones mentales a las que tanto nos aferramos y al que solo nos podemos acercar con una actitud compasiva. Se trata, por tanto, de dejar de lado el juicio y, despojándonos de la tristeza, ser capaces, simplemente, de acompañar.

Medea puede ser leída como víctima o como verdugo. No obstante, Maillard nos recuerda estas palabras de Albert Camus: "La comunidad de las víctimas es la misma que la que une la víctima al verdugo, pero el verdugo no lo sabe" (p. 119). $\mathrm{Y}$ es que, para la autora, la naturaleza no entiende de cercos. La separación que construimos entre violencia y vida no da lugar a la comprensión porque la vida es violencia y viceversa. Mantenernos firmes en las diferencias, en los contrarios, posicionándonos siempre en el vértice más alto para poder contemplar y perdonar la criminalidad esencial del otro es la actitud que nos acerca a la piedad y nos aleja de la compasión. Sin embargo, si ponemos entre paréntesis los códigos morales nos acercamos a él, ya no como un otro sino como un igual, reconociendo lo compartido, iluminando aquello que nos sostiene como parte de la naturaleza que somos. "Si fuésemos capaces de comprender a Medea, pensaba, podríamos perdonar a la humanidad toda entera" (p. 145) —opina Maillard_- De esta forma, el yo es despojado de su autoridad para deshacerse en el oscuro sufrimiento del otro, para vibrar por resonancia con el resto de seres.

Estas ideas se traducen en la tercera y última parte del libro al formato teatral. Medea junto a una mujer también ya anciana encarnan un diálogo donde temas como la culpa, el perdón y la intemperie quedan personificados. Medea habla ahora desde otro lugar; desde una posición que va más allá de lo humano, reflejando el movimiento incontrolable de la existencia y la convivencia de los contrarios. Pero, sobre todo, Medea, finalmente, al unísono con la mujer, retrata ese lugar que está "más abajo", aquel espacio común en el que "todas podemos ser cualquiera" (p. 206). De nuevo, esa ética de la compasión como clave para el reconocimiento y la convivencia.

Recogiendo cada enseñanza contenida en esta obra podríamos preguntarnos: ¿hay lugar en esta sociedad para la compasión difícil? ¿Hay espacio para, en esta dura época sin dioses que nos consuelen ni abrigo de otros dogmas, compartir y comprender el dolor de las otras personas sin juicios y acompañarlas desde una posición de igual a igual? Vivimos en un mundo donde el culto al hedonismo, el nihilismo mercantil y la ceguera voluntaria impregnan toda nuestra realidad y nos 
hallamos constantemente vagando en superficialidades para desviar la atención del sufrimiento. Por esta razón Chantal Maillard nos acerca con plena sinceridad al abismo de la existencia, haciendo imposible mantenerse indiferente ante la brutalidad presentada a lo largo de sus páginas. Con todo, nos ofrece el aprendizaje necesario para ser capaces de nadar en las profundidades comunes que se esconden en lo más recóndito de nuestras vidas, dándonos la clave para que esa oscuridad se atenúe y consigamos acompañar a todos los seres con los que habitamos.

Ana Orellana García

Universidad Autónoma de Madrid

anaorellanag@hotmail.com

Paula Román Cañamero

Universidad Autónoma de Madrid

pauromanc30@gmail.com

Regina Lagos González

Universidad Autónoma de Madrid

reginalagosg@gmail.com 